\title{
KOMPOSISI PAKAN TIKUS EKOR PUTIH (Maxomys hellwandii) DI KANDANG
}

\author{
Fernandez T. Upa ${ }^{1)}$, Saroyo ${ }^{1)}$, Deidy Y. Katili ${ }^{1)}$ \\ ${ }^{1)}$ Program Studi Biologi, FMIPA Universitas Sam Ratulangi Manado \\ e-mail: fernandesupa@yahoo.co.id; yoyoksumarto@gmail.com; deidy.katili@yahoo.co.id;
}

\begin{abstract}
ABSTRAK
Tikus ekor putih (Maxomys hellwandii) adalah hewan endemik Sulawesi dengan status konsevasinya yaitu least concern yang keberadaannya masih kurang diperhatikan. Ancaman utama tikus ekor putih adalah perburuan untuk dijual penelitian ini bertujuan untuk menginventarisasi jenis-jenis pakan tikus ekor putih dan porsinya. Penelitian ini dilakukan untuk memberikan informasi tentang komposisi pakan tikus ekor putih sehingga dapat dimanfaatkan dalam upaya konservasi terutama dalam kegiatan penangkaran dengan upaya domestikasi. Metode yang digunakan dalam penelitian ini ialah ad libitum sampling dengan menghitung berat pakan yang dikonsumsi. Hasil penelitian menunjukkan bahwa komposisi jenis pakan tikus ekor putih terdiri dari: pepaya $(51,3 \%)$, umbi singkong $(15,7 \%)$, buah kelapa $(15,6 \%)$, serangga (belalang) $(13,9 \%)$, daun sirih $(2,9 \%)$, kulit buah ketapang $(0,4 \%)$, buah sirih $(0,2 \%)$, buah beringin $(0,1 \%)$. Dari hasil penelitian tersebut dapat disimpulkan bahwa tikus ekor putih mengonsumsi buah pepaya lebih dari $50 \%$ dari total pakan dan tikus ekor putih bukan spesies herbivora sejati, tetapi cenderung omnivora.
\end{abstract}

Kata kunci: tikus ekor putih (Maxomys hellwandii), endemik, Sulawesi, komposisi pakan

\section{COMPOSITION OF FEED WHITE-TAIL RAT (Maxomys hellwandii) IN THE CAGE}

\begin{abstract}
White-tailed Rat (Maxomys hellwandii) is an endemic species from Sulawesi with least concern (LC) conservation status. The existence of this species is still less attention. The main threat is hunting White-tailed rats for sale, this research aims to inventory the types of feed and the white rat tail portion. This study was conducted to provide information on the composition of the feed white-tailed rats that can be utilized in conservation efforts, especially in the activities of breeding with domesticated effort. The method used in this study was ad libitum sampling to calculate the weight of feed consumed.From the results obtained that the composition of White-tailed Rat feed types such as: papaya $(51.3 \%)$, cassava tubers $(15.7 \%)$, coconuts $(15.6 \%)$, insects (grasshoppers) (13.9\% ), leaf Piper beetle (2.9\%), fruit peel Terminalia catappa (0.4\%), vine Pieper beetle $(0.2 \%)$, fruit Ficus sp. $(0.1 \%)$. From these results it can be concluded that the white-tailed rat eating papaya fruit of more than $50 \%$ of the total feed and white-tailed rat is not true herbivorous species, but tend to be omnivorous.
\end{abstract}

Keywords: white-tailed rat (Maxomys hellwandii), endemic to Sulawesi, feed composition

\section{PENDAHULUAN}

Sulawesi merupakan pulau terbesar yang terletak di tengah-tengah Kawasan Wallacea, yang mempunyai keragaman fauna yang sangat tinggi. Di pulau ini hidup 114 jenis mamalia dan 60 jenis di antaranya asli setempat. Salah satu kekayaan hayati tersebut antara lain tikus ekor putih. Tikus ekor putih (Maxomys hellwandii) adalah hewan endemik Sulawesi. Menurut IUCN (The
International Union For The Conservation of Nature and Natural Resources), status konsevasinya yaitu least concern yang keberadaannya masih kurang diperhatikan. Ancaman utama tikus ekor putih adalah perburuan untuk dijual (Saroyo et al., 2012).

Di Sulawesi Utara, tikus ekor putih sudah sejak lama menjadi bahan pangan eksotik untuk masyarakat khususnya Minahasa. Di Minahasa, tikus ekor putih disebut "turean". Tikus ekor putih "turean" 
dewasa mempunyai warna krem dengan warna putih pada bagian dada dan perutnya. Tikus tersebut mempunyai ukuran tubuh yang relatif kecil, mencari makan di atas pohon pada malam hari dan berliang di tanah pada siang hari, atau pada lubang-lubang yang ada di pohon. Tikus ini hanya terdapat di hutan-hutan pulau Sulawesi (van der Zon, 1979).

Tikus ekor putih mengonsumsi buah kelapa, buah pepaya, daun sirih, buah sirih juga jenis buah dan daun yang ada di hutan. Wahyuni (2005) menambahkan bahwa dalam penangkaran secara $e x$-situ, tikus ekor putih memakan buah-buahan, biji dan kulit buah. Tikus ekor putih juga memakan jenis-jenis arthropoda misalnya serangga (belalang, kumbang, semut, ngengat, dan kecoa).

Selama hidupnya, tikus ekor putih melakukan berbagai aktivitas yang disebut aktivitas harian. Menurut Fraser (1990), aktivitas tikus secara umum meliputi tingkah laku makan, minum, sosial seperti kawin agonistik, afiliatif, tingkah laku istirahat, eksplorasi, dan tingkah laku melahirkan.

Salah satu upaya dalam konservasi tikus ekor putih ialah domestikasi. Dalam upaya domestikasi diperlukan beberapa informasi, antara lain aspek biologis yang meliputi jenis-jenis pakan, perilaku dan aktivitas harian. Upaya penangkaran dapat dikembangkan dalam rangka menyuplai kebutuhan akan permintaan tikus ekor putih yang tinggi tanpa harus menangkap langsung dari alam.

Mengingat pentingnya peranan tikus ekor putih sebagai bagian ekosistem alami dan sumber protein hewani bagi masyarakat Sulawesi Utara, maka penelitian tentang komposisi pakan penting untuk dilakukan.

\section{METODE}

Penelitian ini dilaksanakan pada bulan April sampai Juli 2016 di Laboratorium Biologi Dasar FMIPA Unsrat. Pembuatan kandang sosial menggunakan bahan berupa kayu dan ram kawat. Ukuran dan kondisi kandang didasarkan pada syarat dan ketentuan dalam Guidelines for the Housing of Rats in Scientific Institutions oleh Scharmann (1991). Dalam penelitian ini digunakan 6 tikus dengan ukuran kandang: panjang $120 \mathrm{~cm}$, lebar $70 \mathrm{~cm}$, dan tinggi 60 $\mathrm{cm}$ atau dengan luas $8.400 \mathrm{~cm}^{2}$. Ukuran ini sesuai dengan ketentuan di atas, yaitu minimal untuk 5 tikus ialah $1.500 \mathrm{~cm}^{2}$ atau jika 6 ekor ukuran minimalnya $1.800 \mathrm{~cm}^{2}$. Air minum diberikan secara ad libitum (diberikan secara tak terbatas). Persyaratan suhu ialah $25^{\circ}-30^{\circ} \mathrm{c}$ pada siang hari dan suhu $17^{0}-26^{0} \mathrm{c}$ pada malam hari. Kandang dilengkapi dengan tempat bersembunyi yang dibuat dari tabung paralon dengan panjang $66 \mathrm{~cm}$ dan diameter lingkaran $11,5 \mathrm{~cm}$.

Tahap berikutnya yaitu habituasi yaitu penyesuaian tikus terhadap lingkungan kandang. Habituasi tesebut dilakukan selama 3 hari dengan cara melihat perilaku tikus ekor putih dalam kandang.

Data lingkungan yang diukur selama penelitian yaitu suhu. Suhu diukur selama 5 hari untuk menentukan kestabilan suhu normalnya. Waktu yang diukur yaitu pada pagi, siang, sore, dan malam hari. Pada pagi hari suhu diukur pada pukul 06:00, siang hari pada pukul 12:00 dan 14:00, sore hari pada pukul 18:00 dan malam hari pada pukul 24:00.

Masing-masing jenis pakan diberikan seberat 100 gram pada sore hari. Pada pagi harinya sisa pakan diambil dan ditimbang untuk menentukan porsi setiap jenis pakan yang dikonsumsi tikus digunakan rumus:

Berat pakan dikonsumsi $($ gram $)=$ Berat

pakan awal (gram) - Berat pakan akhir (gram)

Pengamatan dilakukan selama 3 hari. Selanjutnya kuantitas pakan tertinggi setiap jenis pakan ditetapkan sebagai berat pakan awal ditambah $20 \%$ sebagai antisipasi pertumbuhan tikus.

Tikus terlebih dahulu ditimbang dengan menggunakan timbangan neraca untuk diambil berat awal sebelum penelitian. Tikus ditandai pada bagian pangkal ekor, kemudian dilepaskan ke dalam kandang. Pengambilan data untuk komposisi dan porsi pakan dilakukan selama 21 hari. Pemberian pakan dilaksanakan pada sore hari pada pukul 18.00 dan penimbangan sisa pakan dilakukan pada pagi hari pukul 07.00. Pertumbuhan tikus ditentukan dengan menimbang tikus setelah penelitian berakhir (21 hari). Rumus yang digunakan dalam menentukan pertumbuhan ini menurut Cholik et al. (2005) ialah:

Keterangan :

$$
\mathrm{W}=\mathrm{Wt}-\mathrm{Wo}
$$

$\mathrm{Wt}=$ Berat badan akhir 
Wo $=$ Berat badan awal

\section{HASIL DAN PEMBAHASAN}

\section{Manajemen Pemeliharaan Kandang}

Pembuatan kandang sosial dibuat menyerupai habitat aslinya untuk memudahkan aktivitas tikus ekor putih seperti makan, minum, kawin, berpindah, istirahat, eksplorasi, dan aktivitas sosial. Kandang dibuat menggunakan bahan berupa kayu dan ram kawat sehingga tikus tidak mudah keluar. Tikus ditempatkan dalam ruangan berventilasi dengan udara yang alami. Tempat pakan diberikan dalam wadah yang besar dengan semua jenis pakan sehingga tikus ekor putih dapat memilih pakannya. Bagian bawah kandang diletakkan kardus sebagai alas kandang untuk menampung kotoran tikus. Kardus tersebut diganti setiap hari pada pagi hari.

\section{Faktor Lingkungan}

Faktor lingkungan yang diukur pada penelitian ini adalah suhu. Pengamatan suhu selama penelitian, suhu berkisar $25^{\circ} \mathrm{C}-27^{\circ} \mathrm{C}$. Menurut Scharmann (1991), suhu ruangan yang sisarankan untuk tikus berkisar $20^{\circ} \mathrm{c}-26^{\circ} \mathrm{c}$, tetapi untuk daerah hutan hujan tropis suhu yang bisa digunakan berkisar $25^{\circ} \mathrm{c}-30^{\circ} \mathrm{c}$. Dengan suhu tersebut tikus dapat bertahan hidup layaknya di habitat alami.

\section{Komposisi dan Porsi Pakan}

Rata-rata berat pakan yang dikonsumsi tikus ekor putih berturut-turut dari yang tertinggi ke yang terendah ialah pepaya (196,1 gram atau 51,3\%), umbi singkong $(60,1$ gram atau $15,7 \%)$, buah kelapa $(59,8$ atau $15,6 \%)$, serangga (belalang) $(53,1$ gram atau $13,9 \%)$, daun sirih $(11,0$ gram atau $2,9 \%)$, kulit buah ketapang (1,62 gram atau $0,4 \%)$, buah sirih $(0,8$ gram atau $0,2 \%)$, buah beringin $(0,2$ gram atau $0,1 \%)$. Hasil tersebut menunjukkan bahwa tikus ekor putih memakan pepaya lebih dari 50\% dari pakan keseluruhannya (Lampiran).

Hasil penelitian juga menunjukkan bahwa tikus ekor putih mengonsumsi daging, yaitu serangga (belalang) dengan persentase sebesar $13,9 \%$. Hasil ini menunjukkan bahwa tikus ekor putih bukanlah herbivora sejati tetapi cenderung omnivora.

\section{Pertumbuhan}

Spesimen yang digunakan terdiri dari 6 tikus ekor putih dengan penanda yang diberikan yaitu betina dewasa I, betina dewasa II, betina dewasa III, betina pradewasa IV, betina pradewasa $\mathrm{V}$, jantan dewasa VI. Pertambahan berat badan keseluruhan tikus selama periode penelitian 21 hari ialah 109,9 gram. Persentase berat masing-masing tikus betina dewasa I $(20,75 \%)$, tikus betina dewasa II $(18,20 \%)$, tikus betina dewasa III $(25,66 \%)$, tikus betina pradewasa IV $(10,83 \%)$, betina pradewasa $\mathrm{V}(17,29 \%)$, dan tikus jantan dewasa VI (7,28\%) (Tabel 1).

Keperluan penangkaran di kandang, komposisi pakan yang disarankan untuk setiap 100 gram berat badan tikus seperti disajikan pada (Tabel 2). Komposisi pakan tersebut ternyata dapat meningkatkan berat badan tikus dengan rata-rata 109,9 gram dalam waktu 21 hari.

Melimpahnya jumlah pasokan makanan ditambah dengan kualitas lingkungan yang cocok akan memungkinkan semua tikus untuk dapat hidup lebih baik, ini disebabkan, karena energi yang dikeluarkan untuk mendapatkan makanan dan berkompetisi dengan individu lainnya dalam pemanfaatan makanan tidak terlalu besar, sehingga enerigi yang tersisa diginakan untuk pertumbuhan.

Penelitian Fatmal (2008) menyatakan bahwa tikus memakan hewan lain karena pakan dari hewan ini merupakan sumber untuk pertumbuhan dan untuk memperbaiki bagian-bagian tubuh yang rusak, sedangkan pakan yang berasal dari tumbuhan dimanfaatkan sebagai sumber tenaga. Kebutuhan pakan seekor tikus setiap hari kira-kira $10 \%$ dari bobot tubuhnya, tergantung dari kandungan air dan gizi dalam makanannya.

Wahyuni (2005) menyatakan bahwa makanan yang paling disukai tikus ekor putih yaitu buah pisang dan pepaya untuk memenuhi kebutuhan pakannya Wahyuni menambahkan pelet ayam petelur. Untuk memenuhi kebutuhan akan pakan hewani, diberikan juga serangga.

Pada penelitian Gaston et al. (1998) dengan tikus putih (Mus musculus) yang 
diberi pakan pur dan jagung, pertumbuhan berat badan dari $200 \mathrm{~kg}$ menjadi $232 \mathrm{~kg}$ terjadi hal tersebut karena pemberian pur dan jagung memenuhi kebutuhan pakan untuk tumbuh.

Tabel 1. Pertambahan berat badan tikus selama penelitian

\begin{tabular}{|c|c|c|c|c|}
\hline Tikus & $\begin{array}{c}\text { Berat Awal } \\
(\text { Gram })\end{array}$ & $\begin{array}{c}\text { Berat Akhir } \\
(\text { Gram })\end{array}$ & $\begin{array}{c}\text { Pertambahan } \\
\text { Berat (Gram) }\end{array}$ & $\begin{array}{c}\text { Persentase } \\
\text { Pertambahan } \\
\text { Berat (\%) }\end{array}$ \\
\hline Betina Dewasa I & 349,5 & 372,3 & 22,8 & 20,75 \\
\hline Betina Dewasa II & 313,5 & 333,5 & 20,0 & 18,20 \\
\hline Betina Dewasa III & 298,7 & 326,9 & 28,2 & 25,66 \\
\hline Betina Pradewasa IV & 225,5 & 237,4 & 11,9 & 10,83 \\
\hline Betina Pradewasa V & 241,0 & 260,0 & 19,0 & 17,29 \\
\hline Jantan Dewasa VI & 391,7 & 399,7 & 8,0 & 7,28 \\
\hline Total & 1819,9 & 1929,8 & 109,9 & 100 \\
\hline
\end{tabular}

Tabel 2. Berat pakan per 100 gram berat badan tikus (total berat tikus 1819,9 gram)

\begin{tabular}{|c|c|c|}
\hline \multicolumn{2}{|c|}{ Berat Pakan dalam Penelitian (Gram) } & $\begin{array}{c}\text { Berat Pakan untuk } \\
\text { 100 Gram Tikus } \\
\text { (Gram) }\end{array}$ \\
\hline Daun Sirih & 11,0 & 0,60 \\
\hline Buah Sirih & 0,8 & 0,04 \\
\hline Buah Pepaya & 196,4 & 10,79 \\
\hline Buah Beringin & 0,2 & 0,01 \\
\hline Buah Kelapa & 59,8 & 3,29 \\
\hline Kulit Buah Ketapang & 1,6 & 0,09 \\
\hline Ubi Singkong & 60,1 & 3,30 \\
\hline Serangga & 53,1 & 2,91 \\
\hline
\end{tabular}

Pakan ideal untuk tikus yang sedang tumbuh harus memenuhi kebutuhan zat makanan antara lain protein $12 \%$, lemak $5 \%$, dan serat kasar kira-kira 5\%, harus cukup mengandung vitamin $\mathrm{A}$, vitamin $\mathrm{D}$, asam linoleat, tiamin, riboflavin, pantotenat, vitamin B12, biotin, piridoksin dan kolin serta mineral-mineral tertentu. Kandungan kimiawi pada pakan yang diberikan pada tikus harus mengandung asam amino esensial seperti arginin, isoleusin, leusin, methionin, fenilalanin, treonin, tryptofan, dan valine (Wolfenshon and Lloyd, 2013). Dengan begitu kebutuhan pakan tikus bisa terpenuhi.

\section{KESIMPULAN}

Dari hasil dan pembahasan di atas dapat disimpulkan sebagai berikut:

1) Komposisi jenis pakan tikus ekor putih terdiri dari: pepaya $(51,3 \%)$, umbi singkong $(15,7 \%)$, buah kelapa $(15,6 \%)$, serangga (belalang) $(13,9 \%)$, daun sirih $(2,9 \%)$, kulit buah ketapang $(0,4 \%)$, buah sirih $(0,2 \%)$, buah beringin $(0,1 \%)$. Komposisi pakan tertinggi yaitu pepaya dengan persentasi $51,3 \%$ dan terendah buah beringin $0,1 \%$.

2) Tikus ekor putih merupakan spesies yang cenderung omnivora.

\section{DAFTAR PUSTAKA}

Cholik, F., G.J. Ateng, A. Poernomo, dan Fauzi, 2005. Akuakultur, Tumpuan Harapan Masa Depan Bangsa. Masyarakat Perikanan Nusantara dan Taman Akuarium Air Tawar. Jakarta.

Fatmal, I. 2008. Preferensi Tikus (Rattus agentiventer) Terhadap Jenis Umpan Pada Tanaman Padi Sawah. Jurusan HPT Fakultas Pertanian Unsyiah Kuala Banda Aceh. Journal Florantek. 3: 8673.

Fraser, A. F., dan Broom, D.M., 1990. Farm Animal Behavior and Welfare Third Edition. ELBS. New York.

Gaston, K.J. dan J.I. Spicer. 1998. Biodiversity: An Introduction. Blackwell Science. Paris. 
IUCN. 2008.2 Redlist. http://www.iucnredlist.org/details/1289 5/0 [diakses 27 Mei 2016]

Musser, G.G., Weerd A van de, dan E. Strasser. 1986. Paulamys, a replacement name for Floresomys (Muridae), and new material of that taxon from Flores, Indonesia. American Museum Novitates 28 (5): 110.

Saroyo, 2011. Konsumsi Mamalia, Burung, dan Reptil Liar pada Masyarakat Sulawesi Utara dan Aspek Konservasinya. Jurnal Bios Logos. V. I No. 1 pp. 25-31.

Saroyo., E.I.H. Simbala, R. Koneri, R. Siahaan, dan P. Siahaan. 2012. Biologi Konservasi. CV. Patra Media Grafindo. Bandung.

Taylor, K.D. 1978. Range of movement and activity of common rats (Rattus morvegicus) on agricultural land. Journal Appl Ecol15: 663-677.

Van der Zon, A. P. M. 1979. Mammals of Indonesia. UNDP/FAO National Park Development Project.

Wahyuni, I. 2005. Tingkah Laku, Reproduksi, dan Karakteristik Daging Tikus Ekor Putih (Maxomys hellwandii). Disertasi Sekolah Pascasarjana IPB. Bogor.

Wolfernsohn, S., and Lloyd, M. 2013. Handbook of Laboratory Animal Management and Welfare Fourth Edition. Wiley-Blackwell. Paris.

Yoakum, Jim, dan P.D. William. 1971. Wildlife Management Techniques. The Wildlife Society. Washington, DC. 


\section{LAMPIRAN}

Komposisi dan Porsi Pakan

Rata-rata porsi pakan tikus ekor putih selama 21 hari

\begin{tabular}{|c|c|c|c|c|c|c|c|c|c|c|c|c|c|c|c|c|c|c|c|c|c|c|c|c|}
\hline \multirow{2}{*}{$\begin{array}{c}\text { Jenis } \\
\text { Pakan }\end{array}$} & \multicolumn{21}{|c|}{ Jumlah Yang Dimakan (Gram) } & \multirow{2}{*}{ Jumlah } & \multirow{2}{*}{$\begin{array}{l}\text { Rata } \\
\text {-rata }\end{array}$} & \multirow{2}{*}{$(\%)$} \\
\hline & H1 & H2 & H3 & H4 & H5 & H6 & H7 & H8 & H9 & H10 & H11 & H12 & H13 & H14 & H15 & H16 & H17 & H18 & H19 & H20 & H21 & & & \\
\hline $\begin{array}{l}\text { Daun } \\
\text { Sirih }\end{array}$ & 10,0 & 10,6 & 11,6 & 10,9 & 10,9 & 11,9 & 12,0 & 9,3 & 11,0 & 9,9 & 12,0 & 16,9 & 8,3 & 4,0 & 6,3 & 10,8 & 5,3 & 19,5 & 13,1 & 8,7 & 17,0 & 230,0 & 11,0 & 2,9 \\
\hline $\begin{array}{l}\text { Buah } \\
\text { Sirih } \\
\end{array}$ & 0,0 & 0,4 & 0,9 & 0,2 & 0,3 & 1,6 & 0,2 & 1,6 & 1,1 & 0,9 & 2,2 & 1,0 & 0,0 & 0,6 & 0,2 & 1,9 & 0,9 & 1,7 & 0,4 & 0,2 & 1,1 & 17,4 & 0,8 & 0,2 \\
\hline $\begin{array}{l}\text { Buah } \\
\text { Pepaya }\end{array}$ & 194,2 & 206,5 & 214,3 & 207,1 & 201,0 & 196,4 & 179,7 & 207,1 & 215,2 & 214,4 & 202,0 & 162,7 & 149,8 & 206,7 & 191,1 & 201,8 & 207,1 & 188,2 & 191,1 & 194,5 & 194,0 & 4124,9 & $\begin{array}{c}196, \\
4 \\
\end{array}$ & 51,3 \\
\hline $\begin{array}{l}\text { Buah } \\
\text { Beringi } \\
\mathrm{n}\end{array}$ & 0,1 & 0,2 & 0,2 & 0,1 & 0,2 & 0,7 & 0,1 & 0,2 & 0,4 & 0,1 & 0,1 & 0,0 & 0,2 & 0,2 & 0,2 & 0,2 & 0,2 & 0,4 & 0,0 & 0,2 & 0,2 & 4,2 & 0,20 & 0,1 \\
\hline $\begin{array}{l}\text { Buah } \\
\text { Kelapa }\end{array}$ & 46,8 & 66,4 & 62,9 & 56,4 & 56,9 & 52,6 & 59,0 & 74,0 & 53,7 & 59,9 & 63,4 & 67,1 & 40,1 & 60,6 & 66,3 & 63,4 & 58,8 & 70,6 & 78,1 & 31,4 & 67,7 & 1256,1 & 59,8 & 15,6 \\
\hline $\begin{array}{l}\text { Kulit } \\
\text { Buah } \\
\text { Ketapa } \\
\text { ng }\end{array}$ & 3,5 & 1,4 & 2,2 & 1,3 & 2,0 & 5,0 & 1,9 & 1,0 & 1,0 & 1,5 & 1,8 & 0,6 & 0,7 & 1,6 & 1,7 & 0,5 & 0,6 & 0,9 & 0,5 & 0,8 & 3,5 & 34,0 & 1,62 & 0,4 \\
\hline $\begin{array}{l}\text { Ubi } \\
\text { Singko } \\
\text { ng }\end{array}$ & 59,3 & 77,0 & 96,9 & 97,0 & 76,9 & 67,7 & 65,7 & 70,2 & 48,9 & 57,9 & 37,6 & 75,3 & 34,3 & 53,6 & 74,5 & 35,1 & 39,1 & 42,0 & 65,6 & 40,2 & 47,8 & 1262,6 & 60,1 & 15,7 \\
\hline $\begin{array}{l}\text { Serang } \\
\text { ga } \\
\text { (Belala } \\
\text { ng) }\end{array}$ & 65,1 & 52,1 & 53,0 & 57,6 & 52,7 & 63,3 & 57,8 & 56,3 & 61,3 & 57,9 & 51,8 & 54,3 & 60,5 & 55,7 & 45,3 & 39,7 & 56,3 & 39,7 & 47,8 & 33,7 & 53,7 & 1115,6 & 53,1 & 13,9 \\
\hline Jumlah & 379,0 & 414,6 & 442,0 & 430,6 & 400,9 & 399,2 & 376,4 & 419,7 & 392,6 & 402,5 & 370,9 & 377,9 & 293,9 & 383,0 & 385,6 & 353,4 & 368,3 & 363,0 & 396,6 & 309,7 & 385,0 & 8044,8 & $\begin{array}{c}383, \\
1\end{array}$ & 100 \\
\hline
\end{tabular}

